Article

\title{
Hybrid Moth-Flame Optimization Algorithm and Incremental Conductance for Tracking Maximum Power of Solar PV/Thermoelectric System under Different Conditions
}

\author{
Hegazy Rezk ${ }^{1,2, *(\mathbb{D}}$, Ziad Mohammed Ali ${ }^{1,3} \mathbb{D}^{-}$, Omer Abdalla ${ }^{1,4}$, Obai Younis ${ }^{1,5} \mathbb{D}^{\text {, Mohamed }}$ \\ Ramadan Gomaa ${ }^{6,7}$ (D) and Mauia Hashim ${ }^{8}$ \\ 1 College of Engineering at Wadi Addawaser, Prince Sattam Bin Abdulaziz University, Al Kharj 11991, Saudi \\ Arabia; dr.ziad.elhalwany@aswu.edu.eg (Z.M.A.); o.abdalla@psau.edu.sa (O.A.); \\ o.elamin@psau.edu.sa (O.Y.) \\ 2 Electrical Engineering Dept., Faculty of Engineering, Minia University, Minya 61519, Egypt \\ 3 Electrical Engineering Dept., Faculty of Engineering, Aswan University, Aswan Governorate 81528, Egypt \\ 4 University of Medical Sciences \& Technology, Khartoum 11111, Sudan \\ 5 Mechanical Engineering Department, Faculty of Engineering, University of Khartoum, Al Khurtum 11111, Sudan \\ 6 Mechanical Department, Faculty of Engineering, Mu'tah University, Al-Karak 61710, Jordan; \\ behiri@bhit.bu.edu.eg \\ 7 Mechanical Department, Benha Faculty of Engineering, Benha University, Benha 13512, Egypt \\ 8 Sudan Academy of Science, Khartoum 11111, Sudan; mouiahashimtaha@yahoo.com \\ * Correspondence: hr.hussien@psau.edu.sa or hegazy.hussien@mu.edu.eg
}

Received: 29 June 2019; Accepted: 17 September 2019; Published: 20 September 2019

\begin{abstract}
For an efficient energy harvesting by the PV/thermoelectric system, the maximum power point tracking (MPPT) principle is targeted, aiming to operate the system close to peak power point. Under a uniform distribution of the solar irradiance, there is only one maximum power point (MPP), which easily can be efficiently determined by any traditional MPPT method, such as the incremental conductance (INC). A different situation will occur for the non-uniform distribution of solar irradiance, where more than one MPP will exist on the power versus voltage plot of the PV/thermoelectric system. The determination of the global MPP cannot be achieved by conventional methods. To deal with this issue the application of soft computing techniques based on optimization algorithms is used. However, MPPT based on optimization algorithms is very tedious and time consuming, especially under normal conditions. To solve this dilemma, this research examines a hybrid MPPT method, consisting of an incremental conductance (INC) approach and a moth-flame optimizer (MFO), referred to as (INC-MFO) procedure, to reach high adaptability at different environmental conditions. In this way, the combination of the two different algorithms facilitates the utilization of the advantages of the two methods, thereby resulting in a faster speed tracking with uniform radiation distribution and a high accuracy in the case of a non-uniform distribution. It is very important to mention that the INC method is used to track the maximum power point under normal conditions, whereas the MFO optimizer is most relevant for the global search under partial shading. The obtained results revealed that the proposed strategy performed best in both of the dynamic and the steady-state conditions at uniform and non-uniform radiation.
\end{abstract}

Keywords: energy efficiency; photovoltaic module; MPPT; optimization; computational fluid dynamics (CFD) 


\section{Introduction}

A rapid increase of utilized fossil fuels and the limitation on producing this fuel in a large number of countries around the world has led to the depletion of fossil fuel, increasing the price and causing environment problems such as acid rain, air pollution and global warming [1,2]. Photovoltaic (PV) system is considered an effective way to capture solar irradiance and directly converts it to electricity [3,4]. At the present time, PV systems are employed in different applications such as water pumping and charging vehicle batteries [5-7]. PV solar cell conversion efficiency is considered relatively low, within the range of $10-20 \%$ for commercial silicon cell and up to $40 \%$ for most multi-junction cells. For better overall PV energy efficiency generation, the application of cogeneration technique is widely attracting the researcher's attention, and this is achieved by capturing the waste heat as well and using it as an auxiliary energy production source. This can be done by incorporating a PV panel and thermoelectric generator (TEG) forming the so-called Hybrid photovoltaic/ thermoelectric generator (HPVTEG) system, which is increasingly attracting considerable interest among the issues of energy conversion efficiency improvement. HPVTEG system that integrates PV panel and TEG comprises double layer elements; the upper layer representing the PV panel, and a TEG at the bottom layer. TEG is fixed at the back of the PV module, which in turn utilizes the thermal waste to generate an additional electricity. The hot side of the TEG is connected to the backside of the PV panel and the cold side will be attached by heat sink as illustrated in Figure 1a. Figure $1 \mathrm{~b}$ shows a typical schematic diagram of the HPVTEG. During the next few years, the TEGs are expected to attract profound applications as a prospective source of electricity [8]. They convert the embedded thermal energy into electricity, in such a way that, depending on the temperature difference across them, all possess a typical low conversion efficiency [9]. There are several TEGs arrangements in the electrical circuits to obtain the specified voltage and current. The major drawback to apply the TEG technology is their low efficiency and inconsistent power output due to the temperature fluctuations. The TEG is a metal interconnected thermocouple consisting of a series $p$ and $n$-types pellets.

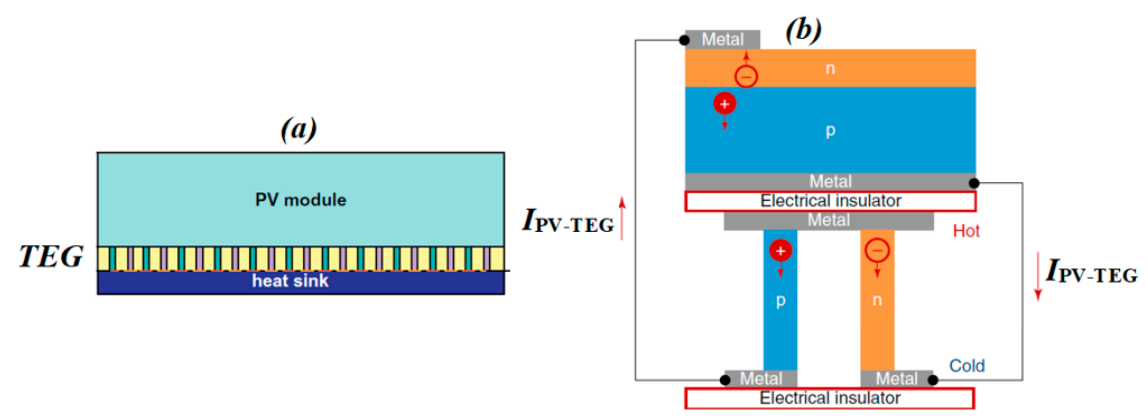

Figure 1. Schematic overview of the HPVTEG system.

The hybrid photovoltaic thermoelectric system is classified according to the way of their connection to a non-concentric and concentric, and their detailed classification is given in Figure 2. 


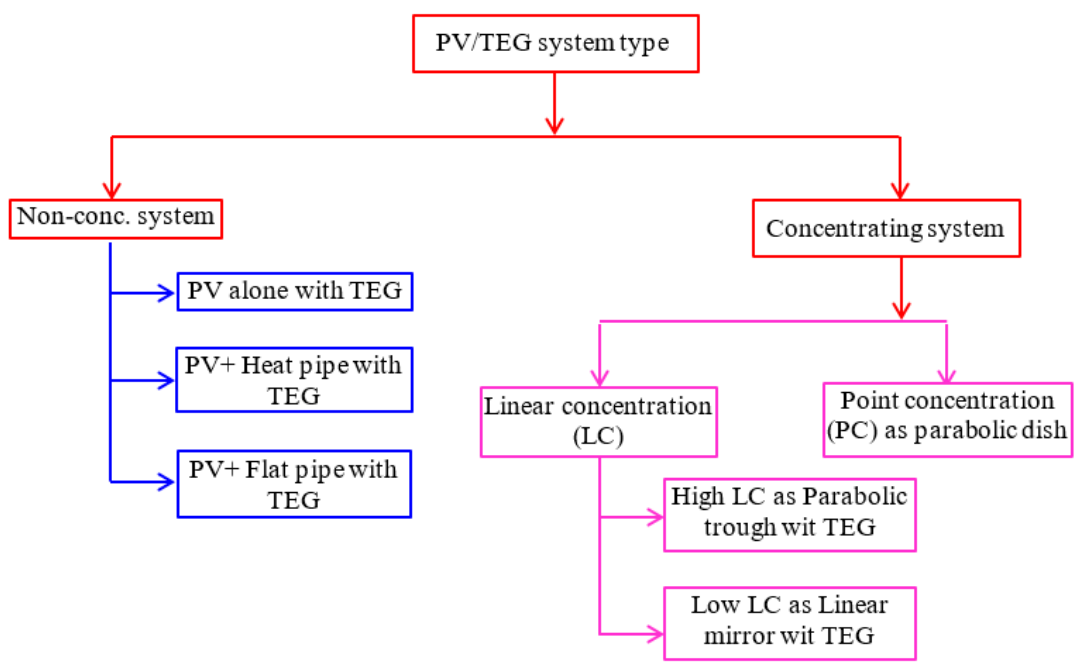

Figure 2. HPVTEG System Classifications.

Based on the temperature coefficient, and the concentration of the heat, the efficiency of the system will vary accordingly [10], and it was found that the hybrid model efficiency is better than that of a single PV solar cell only. The performance of HPVTEG system was investigated in several works of research [11-19]. Zhang et al. [11] presents the feasibility and features of the integrated system consisting of the PV solar cell and TEG. The obtained results confirm that the HPVTEG system is viable and the overall efficiency is enhanced. The theoretical simulation proved that the efficiency of hybrid system is improved by $30 \%$ by adding the TEG to the backside of the solar PV panel [18]. The enhancement of the conversion efficiency predicted by Sark was about 23\% [17]. Experimentally, a 100 W prototype of a hybrid model was validated, tested, and implemented to an automobile [19]. In this work, the exhaust gas waste heat energy recovery for automobiles through TEG. New hybrid models were designed, constructed, into variances, with different solar cell and collectors, which were fixed on the hot and cold layers, respectively and then were tested. This PV-TEG-STC (solar collector) model used for producing electrical and thermal energy actually is facing two setbacks; the relatively lower TEG generated output power and the higher module cost [13]. These obstacles were overcome by increasing the solar collector exposure area and choosing a cheaper TEG. In addition, the hybrid system HPVTEG was implemented experimentally to hybrid electric vehicles proved that it was an efficient energy source [14]. With a sun-tracking arrangement, this model proved very efficient compared with the corresponding traditional units [15]. It is very important to notice that the hybrid model output is dependent on the temperature difference between the two sides of the TEG; once it is increased, the output will increase also. As a solution, Reference [16] suggested to optimize the coolant flow rate. The heat flux distributions and the heat transfer was numerically studied by using finite element method. The results show that the integrated design characteristic and performance was enhanced for both of TEG and solar cell. Table 1 summarizes the overall power and performance of different PV/TEG systems. 
Table 1. The overall performances of different PV/TEG systems.

\begin{tabular}{|c|c|c|c|c|c|c|}
\hline \multicolumn{2}{|c|}{ Type of PV/TEG } & \multirow{2}{*}{$\Delta \mathrm{T}(\mathrm{\circ C})$} & \multirow{2}{*}{$\begin{array}{l}\text { Overall Power } \\
\text { (MW) }\end{array}$} & \multirow{2}{*}{$\begin{array}{l}\text { Overall Efficiency } \\
\text { (\%) }\end{array}$} & \multirow{2}{*}{ Reference } & \multirow{2}{*}{ Remark } \\
\hline PV & TEG & & & & & \\
\hline Perovskite & ceramic & - & - & 18.6 & [11] & $\begin{array}{l}\text { Solar selective absorber (SSA) was } \\
\text { used, Concentration ratio }(\mathrm{CR})=1\end{array}$ \\
\hline Monocrystalline & $\mathrm{Bi}_{2} \mathrm{Te}_{3}$ & 5.9 & $\begin{array}{c}\text { 7\% power increasing, } 3.4 \mathrm{~mW} \text { of } \\
\text { TEG }\end{array}$ & 18.93 & \multirow[t]{3}{*}{ [20] } & \multirow{3}{*}{ Simulation $720-1020 \mathrm{~W} / \mathrm{m}^{2}$} \\
\hline Polycrystalline & $\mathrm{Bi}_{2} \mathrm{Te}_{3}$ & 5.6 & $\begin{array}{c}\text { 7\% power increasing, } 3.44 \mathrm{~mW} \text { of } \\
\text { TEG }\end{array}$ & 16.71 & & \\
\hline $\begin{array}{l}\text { amorphous } \\
\text { silicon }\end{array}$ & $\mathrm{Bi}_{2} \mathrm{Te}_{3}$ & 3.4 & $\begin{array}{c}5 \% \text { increasing power, } 1.12 \mathrm{~mW} \text { of } \\
\text { TEG }\end{array}$ & 2.88 & & \\
\hline c-Si & $\mathrm{Bi}_{2} \mathrm{Te}_{3}$ & 15 & 65.2 & 16.3 & {$[18]$} & - \\
\hline $\mathrm{c}-\mathrm{Si}$ & Not mentioned & 52 & 24,500 (9 solar cells) & 23 & [21] & - \\
\hline Poly-Si & $\mathrm{Bi}_{2} \mathrm{Te}_{3}$ & 36 & 2290 & 12.4 & [22] & - \\
\hline Cd-free CIGS & $\mathrm{Bi}_{2} \mathrm{Te}_{3}$ & 11.6 & - & 22.02 & [23] & Use of nanowire $(\mathrm{ZnO})$ \\
\hline DSSC & $\mathrm{Bi}_{2} \mathrm{Te}_{3}$ & 6.2 & 13.8 per $\mathrm{cm}^{2}$ & 13.8 & {$[24]$} & SSA was used \\
\hline DSSC & $0.89 \% \mathrm{Bi}_{2} \mathrm{Te}_{3}$ in $\mathrm{TiO}_{2}$ anode & 15 & - & 7.33 & [25] & - \\
\hline DSSC & $\begin{array}{c}\text { p-type; } \mathrm{Bi}_{0.4} \mathrm{Sb}_{1.6} \mathrm{Te}_{3} \mathrm{n} \text {-type; } \\
\mathrm{Bi}_{2.85} \mathrm{Se}_{0.15} \mathrm{Te}_{3}\end{array}$ & - & - & 9.08 & [26] & - \\
\hline Polymer solar cell & $\mathrm{Bi}_{2} \mathrm{Te}_{3}$ & 9.5 & 11.29 per $\mathrm{cm}^{2}$ & - & {$[27]$} & - \\
\hline Polymer solar cell & $\mathrm{Bi}_{0.4} \mathrm{Sb}_{1.6} \mathrm{Te}_{3}$ & - & - & $\sim 13.4$ & {$[28]$} & Concentration system, $\mathrm{CR}=1$ \\
\hline Thin film & Bi2Te3,ZnSb & 85 & $19.13 \mu \mathrm{W}$ for TEG only & - & [29] & \\
\hline DSSC & $\mathrm{Bi}_{2} \mathrm{Te}_{3}$ & 20 & $\begin{array}{l}11.2 \% \text { increase compared to PV } \\
\text { alone }\end{array}$ & - & {$[30]$} & \\
\hline DSSC & $\mathrm{Bi}_{2} \mathrm{Te}_{3}$ & 6.2 & - & $\begin{array}{c}13 \% \text { increase } \\
\text { compared to PV alone }\end{array}$ & {$[22]$} & Using selective layer absorber \\
\hline Multicrystalline & $\mathrm{Bi}_{2} \mathrm{Te}_{3}$ & 27 & - & 35 & [17] & Theoretical with $1000 \mathrm{~W} / \mathrm{m}^{2}$ \\
\hline Polycrystalline & $\mathrm{Bi}_{2} \mathrm{Te}_{3}$ & 40 & - & 11.3 & [31] & Numerical model $100-1000 \mathrm{~W} / \mathrm{m}^{2}$ \\
\hline Polycrystalline & \multirow[t]{2}{*}{$\mathrm{Bi}_{2} \mathrm{Te}_{3}$} & \multirow{2}{*}{$\begin{array}{l}\text { Module temp. } \\
25-86^{\circ} \mathrm{C} \\
\text { cold side temp. } \\
\text { constant } 20^{\circ} \mathrm{C}\end{array}$} & $\begin{array}{l}22.5 \% \text { increasing power, } 2.26 \mathrm{~W} \\
\text { of TEG }\end{array}$ & $\begin{array}{c}\text { 30-40 with } 1.6 \mathrm{~mm} \\
\text { TEG } \\
\text { thick }\end{array}$ & \multirow[t]{2}{*}{ [22] } & \multirow{2}{*}{$\begin{array}{l}\text { Laboratory experimentation } \\
1000 \mathrm{~W} / \mathrm{m}^{2} \\
1.6 \mathrm{~mm} \text { thickness of TEG } \\
\text { cools the module than } \\
\text { the } 1 \mathrm{~mm} \text { thickness, but } 1 \mathrm{~mm} \text { gives } \\
\text { more performance than } 1.6 \mathrm{~mm}\end{array}$} \\
\hline Dyesensitized & & & $\begin{array}{l}22.5 \% \text { increasing power, } 2.28 \mathrm{~W} \\
\text { of TEG }\end{array}$ & $\begin{array}{c}30-45 \\
\text { with } 1 \mathrm{~mm} \text { TEG } \\
\text { thickness }\end{array}$ & & \\
\hline
\end{tabular}

Note: The table key is c-Si: crystalline Si, CIGS; copper indium gallium selenide; Bi: Bismuth; Te: Tellurium; Pb: Lead; Si: Silicon; Ge: Germanium; Zn: Zinc; Sb: Antimony; Cd: Cadmium; SSA: Solar selective absorber; CR: concentration ratio. 
Terminating the HPVTEG with a load equivalent to the internal resistance of the system will facilitate to harvest a maximum power, and this is in compliance with the maximum power transfer principle, therefore, and accordingly the system operating point will be shifted to its peak value. The maximum power point tracker usually comprises a DC-to-DC power converter, controlled in such way that always maximizes the system output power, under the all-operating conditions. By this way a matching of the HPVTEG virtual load to its actual internal resistance by varying the duty cycle of the converter. If the HPVTEG has a direct connection with the load, then it's working point would be set by the load impedance, which indicates that the system will not produce its maximum power [32,33]. In general, this type of power tracking will enable an efficient interfacing of the HPVTEG system with the converter, to transfer a highest power at a fixed voltage. Various papers were dedicated to track the PV solar systems peak power point under variable environmental conditions. These techniques include; fractional open-circuit voltage, short-circuit current, the Artificial Neural Network (ANN) technique [33], Incremental Conductance Method, Hill Climbing Method, and the Fuzzy Logic control [32]. Conventional MPPT methods can easy extract the MPP under uniform distribution of solar radiation. Nevertheless, under partial shading condition (PSC), they cannot extract the global MPP since multiple local MPPs are exhibited on the power against voltage curve of HPVTEG system. Several MPPTs, based on modern optimization are proposed to solve this problem. These methods include; particle swarm optimization [34], cuckoo search [34], mine blast optimization [35], teaching learning based optimization [36], flower pollination and differential evolution [37]. Although the advantages of the several optimization algorithms have been expressed in the literature, it has been demonstrated by the No-Free-Lunch Theorem [38] that none of these algorithms can solve all optimization problems. Such theorem confirms the significance of recent optimizers in various applications since the efficacy of an optimizer to solve a set of problems does not guarantee its success in other application. The main drawback of soft computing based global MPPT techniques is that they are time consuming. Therefore, the main objective of this research is focused on building up a hybrid MPPT technique that combines incremental conductance (INC) and moth-flame optimizer by Mirjalili [39] to achieve better adaptability in various environments. The incorporation of the two different algorithms leads to the utilization of the advantages of both methods, thereby providing faster tracking speed with a uniform radiation distribution and high accuracy with a non-uniform radiation distribution.

\section{HPVTEG System Components}

The considered HPVTEG system mainly consists of a PV panel, TEG bank, DC/DC booster converter, control system, and the load as illustrated in Figure 3. As shown in Figure 3, to save cost, the TEG bank is connected in series with PV panel in order to use only one controller and one DC-DC converter instead of using two controllers with two DC-DC converters when TEG bank and PV panel are connected in parallel. The PV solar panel has three bypass diodes for minimizing and preventing the hotspot problems during partial shading. The MPP tracking methods are employed to increase the harvested energy from HPVTEG system under normal and abnormal conditions. They are used to adjust the DC-DC converter duty-cycle for controlling the operating voltage and current to extract maximum output from the hybrid system. TEG bank consisting of 72 units, divided into two sub-groups is adopted. Each group includes six strings, having six serially connected units each. Three switches, S1, S2 and S3, are used to switch between the serial and parallel connections of the two sub-groups inside the TEG bank. Figure 4 illustrates the flow chart of the proposed strategy. The proposed strategy uses the measured voltages across each bypass diode in order to control the configuration of TEG bank and identify the tracking mode of operation. 


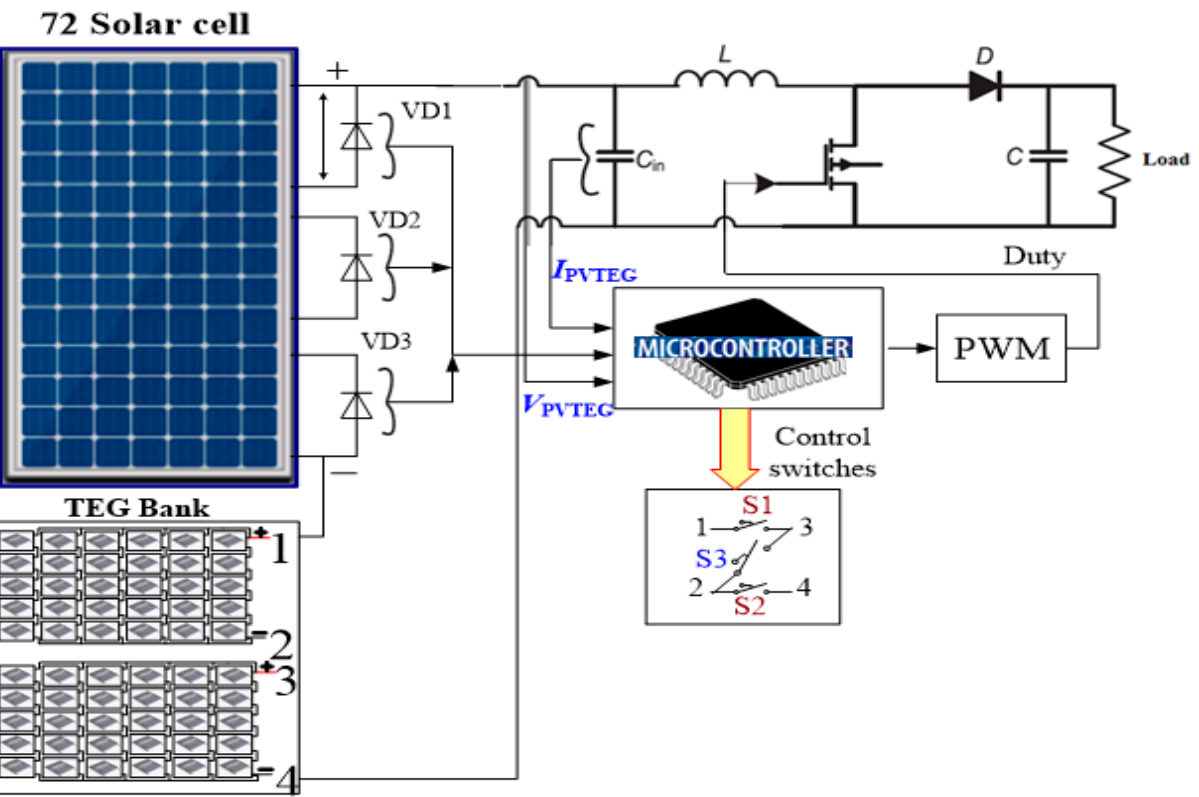

Figure 3. Schematic diagram of HPVTEG integrated with MPPT.

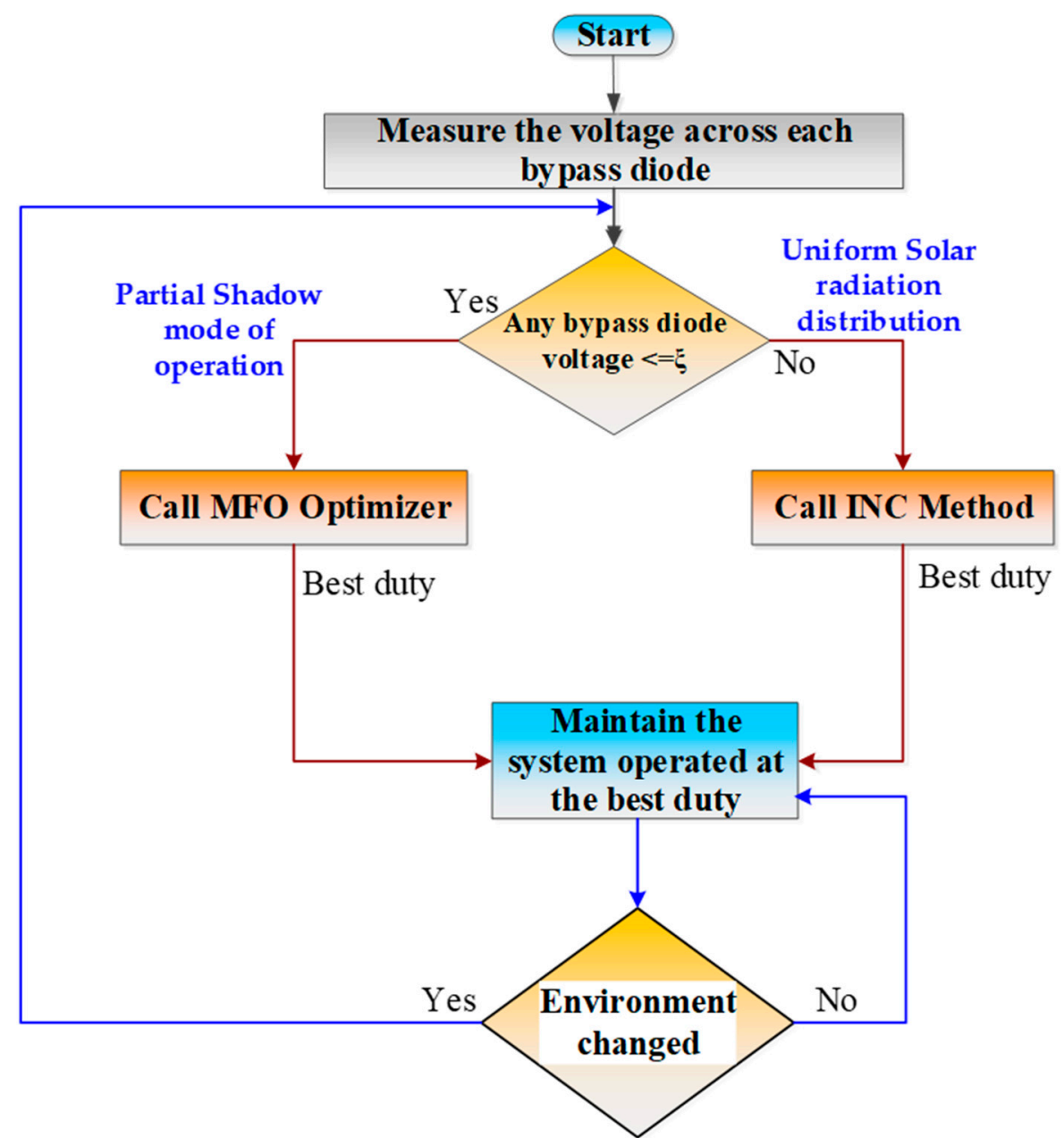

Figure 4. Flowchart of the proposed strategy. (Note: $\xi$ denotes very small value). 


\subsection{Solar Panel}

For this research a Trina solar panel type (TSM-205DA01A.05) was adopted, which consists of 72 multi-crystalline silicon solar cells, connected in series with a power rating of $205 \mathrm{~W}$ at $1000 \mathrm{~W} / \mathrm{m}^{2}$. Each 24 solar cells are shunted by a bypass diode [40]. These diodes are reversed biased during the uniform solar radiation distribution while under shadowing effect; they are forward biased and carry the current instead of the PV panel. Trina solar panel electrical specifications are given in Table 2. The power vs. voltage curves under uniform and non-uniform solar radiation distributions are shown in Figure 5, while the test results of a PV panel is shown in Table 3. Figure 5 shows that the power-voltage characteristics have so many maximum points, equal to the number of irradiance levels incident on the PV module in the case of the partial shading condition. Whereas it has one single MPP at uniform solar radiation distribution.

Table 2. The electrical specifications of Trina solar panel.

\begin{tabular}{ll}
\hline \multicolumn{1}{c}{ Item } & Specification \\
\hline Module & Trina Solar TSM-205DA01A.05 \\
\hline Maximum power $(\mathrm{W})$ & 205 \\
\hline Cells per module & 72 \\
\hline Open-circuit voltage $\left(V_{\mathrm{oc}}\right)(\mathrm{V})$ & 46.6 \\
\hline Short-circuit current $\left(I_{\mathrm{sc}}\right)(\mathrm{A})$ & 5.66 \\
\hline Voltage at MPP $(\mathrm{V})$ & 38.6 \\
\hline Current at MPP $(\mathrm{A})$ & 5.32 \\
\hline Temperature coefficient of $V_{\mathrm{oc}}(\% /$ deg.C) & -0.034 \\
\hline Temperature coefficient of $I_{\mathrm{sc}}(\% /$ deg.C) & 0.04 \\
\hline Light generated current $(\mathrm{A})$ & 5.6825 \\
\hline Diode saturation current $(\mathrm{A})$ & $9.0933 \times 10^{-11}$ \\
\hline Diode ideality factor & 1.0142 \\
\hline Shunt resistance $($ ohms $)$ & 402.5112 \\
\hline Series resistance (ohms) & 0.4372 \\
\hline
\end{tabular}

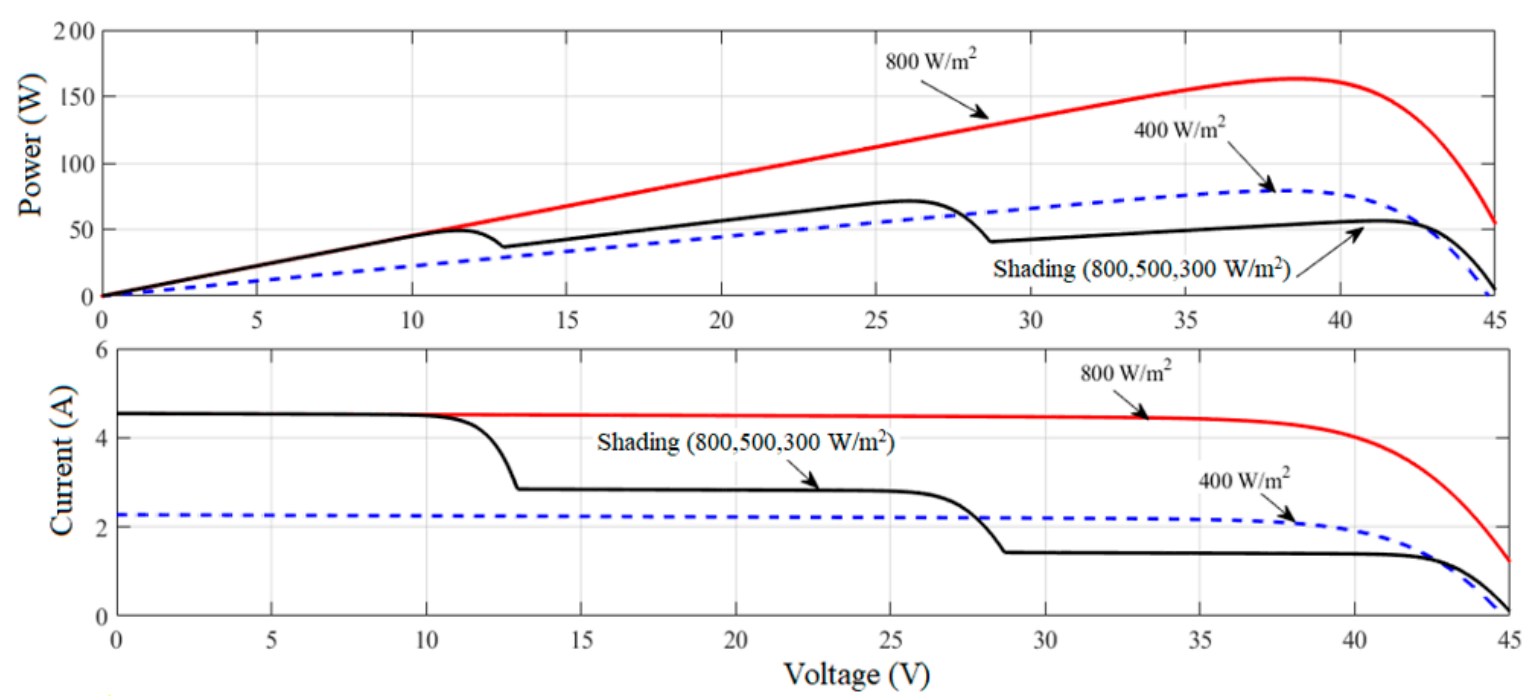

Figure 5. Trina solar panel characteristics under different solar radiation distributions. 
Table 3. Characteristics of PV panel under different conditions.

\begin{tabular}{cccc}
\hline Radiation & Voltage, $\mathbf{V}$ & Current, $\mathbf{A}$ & Power, $\mathbf{W}$ \\
\hline $800, \mathrm{~W} / \mathrm{m}^{2}$ & 38.57 & 4.23 & 163.29 \\
\hline 400 & 38.10 & 2.07 & 79.10 \\
\hline Shading $\left(800,500,300 \mathrm{~W} / \mathrm{m}^{2}\right)$ & 26.07 & 2.74 & 71.45 \\
\hline
\end{tabular}

\subsection{Thermoelectric Generator Modeling}

TEG consists of a thermocouple, made of a metal interconnected $p$ and n-type pellets. Normally the thermocouples are arranged in serially connected arrays, to increase the operating voltage, and thermally in parallel to decrease the thermal resistance, and they are interlapped between two ceramic heat sinks at its two ends for a uniform thermal expansion. One of the two sinks has a higher temperature, and will be known as the hot side of the TEG; while the other has a lower temperature, designated as the cold side [41].

The phenomenon whereby the presence of a temperature difference between any two semiconductors, a thermos-electromotive force will be induced, and this is known as a Seebeck Effect, which is considered to be the basic principle of the TEG [42]. The open-circuit thermo-electro motive force $V_{\mathrm{OC}}$ is given by the following equation:

$$
V_{\mathrm{oc}}=\alpha \times\left(T_{\mathrm{h}}-T_{\mathrm{c}}\right)=\alpha \times \Delta T
$$

where:

$T_{\mathrm{h}}$ and $T_{\mathrm{c}}$-the hot and cold side temperatures.

$\Delta T$ - the junction temperature difference.

$\alpha$-Seebeck coefficient.

The Seebeck coefficient characterizes the induced e.m.f, when the temperature at the junction is increased by $1^{\circ} \mathrm{C}$. Usually metals possess smaller coefficient values. Another physical effect, known as the Peltier Effect, states that if a direct current flows through a junction between two different metal layers, one junction will be heated and the other will be cooled, the heat absorption and dissipation direction depends on the current polarity. The Peltier coefficient is then defined as;

$$
\pi=\frac{P_{\mathrm{p}}}{I_{\text {teg }}}
$$

where:

$P_{\mathrm{P}}$ denotes heat-transfer rate;

$I_{\text {teg }}$ denotes DC current flowing in the TEG.

The Peltier coefficient characterizes the amount of the junction heat either at heating or cooling, meanwhile, the reversible absorption or liberation of heat in a homogeneous material simultaneously exposed to a thermal gradient upon the flow of an electric current, defines the so-called Thomson Effect.

The conductor's heat dissipation when the current flows toward the higher temperature is given by:

$$
P_{\mathrm{T}}=\tau I_{\text {teg }} \Delta T
$$

where:

$\tau$ denotes Thomson coefficient.

Both the Seebeck and Peltier coefficients characterize the metal junctions, so they can be determined only for a pair of junctions, while the Thomson coefficient characterizes an individual conductor. 
Peltier coefficient can be formulated as follows:

$$
\begin{gathered}
\pi=\alpha T_{\mathrm{j}} \\
P_{\mathrm{p}}=\alpha I_{\text {teg }} T_{\mathrm{j}}
\end{gathered}
$$

The current flow through the TEG will cause an additional heat generation in the thermocouples, and this effect of heat dissipation is observed in both sides at different temperatures, but with the same amount of energy as follows:

$$
P_{\mathrm{j}}=\frac{Q_{\mathrm{j}}}{2}=0.5 I_{\mathrm{teg}}^{2} R_{\mathrm{int}}
$$

where $Q_{\mathrm{j}}$ is the Joule heating.

The steady-state analysis at the both sides of the TEG, based on the energy equilibrium concept, the absorbed heat generated by the thermal load and the liberated heat removed by the heat sink can be represented respectively by the following equations [42]:

$$
\begin{aligned}
& Q_{\mathrm{h}}=\alpha I_{\text {teg }} T_{\mathrm{h}}+\kappa_{\mathrm{tc}} \Delta T-0.5 I_{\text {teg }}{ }^{2} R_{\text {int }} \\
& Q_{\mathrm{c}}=\alpha I_{\text {teg }} T_{\mathrm{c}}+\kappa_{\mathrm{tc}} \Delta T+0.5 I_{\text {teg }}{ }^{2} R_{\text {int }}
\end{aligned}
$$

where:

$k_{\mathrm{tc}}$ is the thermal conductivity.

The electrical power is equal to the difference between heat flow at the hot and the cold sides [42]:

$$
\begin{aligned}
P_{\text {teg }} & =Q_{\mathrm{h}}-Q_{\mathrm{c}}=\alpha\left(T_{\mathrm{h}}-T_{\mathrm{c}}\right) I_{\text {teg }}-I_{\text {teg }}{ }^{2} R_{\text {int }} \\
& =\left(\alpha \Delta T-I_{\text {teg }} R_{\text {int }}\right) I_{\text {teg }}=V_{\text {teg }} I_{\text {teg }}
\end{aligned}
$$

where:

$R_{\text {int }}$ and $I_{\text {teg }}$ - the TEG electrical resistance and current respectively.

With reference to Kirchhoff's voltage law, the TEG terminal voltage $\left(V_{\text {teg }}\right)$ will be given by:

$$
V_{\text {teg }}=V_{\mathrm{oc}}-R_{\text {int }} \times I_{\text {teg }}
$$

The datasheet of the commercial TEGs includes the following parameters: $T_{\mathrm{h}}$ and $T_{\mathrm{c}}$, hot and cold-sides temperatures; $P_{\mathrm{m}}$, the matched load power; $R_{\mathrm{int}}$, matched load resistance; $V_{\mathrm{m}}$ the load voltage at the matched load. Obviously, it is very easy to calculate the equivalent circuit parameters from the datasheet. The internal resistance $R_{\text {int }}$ and the Seebeck coefficient $\alpha$ of a TEG can be given by:

$$
\begin{gathered}
R_{\mathrm{int}}=R_{\mathrm{L}}=\frac{V_{\mathrm{m}}^{2}}{P_{\mathrm{m}}} \\
\alpha=\frac{2 V_{\mathrm{m}}}{\Delta T}
\end{gathered}
$$

In this work, a 1 Watt thermoelectric module has been used. Table 4 shows the electrical specifications and dimensions of a TE-MOD-1W2V-40S: 
Table 4. Electrical specifications and dimensions of a TE-MOD-1W2V-40S [43].

\begin{tabular}{lcc}
\hline \multicolumn{1}{c}{ Item } & Unit & Ratings \\
\hline Hot side temperature & ${ }^{\circ} \mathrm{C}$ & 100 \\
\hline Cold side temperature & ${ }^{\circ} \mathrm{C}$ & 20 \\
\hline Open-circuit voltage & $\mathrm{V}$ & 4.0 \\
\hline Matched load resistance & $\Omega$ & 3.25 \\
\hline Matched load output voltage & $\mathrm{V}$ & 2.6 \\
\hline Matched load output current & $\mathrm{A}$ & 0.8 \\
\hline Matched load output power & $\mathrm{W}$ & 0.84 \\
\hline Heat flow density & $\mathrm{W} \mathrm{cm}{ }^{-2}$ & 7 \\
\hline Dimension (A $\times \mathrm{B})$ & $\mathrm{mm}$ & $40 \times 40$ \\
\hline & ${ }^{\circ} \mathrm{C}$ & 75 \\
\hline Hot side temperature & ${ }^{\circ} \mathrm{C}$ & 30 \\
\hline Cold side temperature & $\mathrm{V} /{ }^{\circ} \mathrm{C}$ & $115.5 \times 10^{-3}$ \\
\hline Seebeck coefficients & $\mathrm{W} / \mathrm{m}^{2} \mathrm{~K}$ & 0.67 \\
\hline Thermal conductivity & &
\end{tabular}

\section{Conventional MPPT based on Incremental Conductance}

The INC technique is widely considered the most convenient algorithm for the maximum power tracking under uniform distribution of solar irradiance [44]. Under normal operation of PV system, the PV power versus PV voltage graph contains single the peak point. This point actually represents the MPP at which the PV module produces its maximum power. The core idea of the INC method is that PV power derivative w.r.t its voltage is zero at the MPP [44]. The derivative of power against voltage can be represented by Equation (13) and accordingly, the error signal may be calculated as in Equation (14) [45]. Figure 6 shows INC method flowchart.

$$
\frac{d p_{P V}}{d v_{P V}}=\frac{d\left(v_{P V} * i_{P V}\right)}{d v_{P V}}=\frac{d i_{P V}}{d v_{P V}} * v_{P V}+i_{P V}
$$

and the error signal will be given as:

$$
e=\frac{d i_{P V}}{d v_{P V}}+\frac{i_{P V}}{v_{P V}}
$$

Accordingly, tracking the MPP needs the following strategy:

$$
\begin{cases}\text { 1) } D(\text { new })=D(\text { old })+K * e & \text { when } e>0 \\ \text { 2) } D(\text { new })=D(\text { old }) & \text { when } e=0 \\ \text { 3) } D(\text { new })=D(\text { old })-K * e & \text { when } e<0\end{cases}
$$

where, $K$ is the integrator gain.

It is preferable to start the tracking process with large step size for a quick allocation of the peak power point, then gradually reduce it, when the working point is near to the specified, to reduce oscillations around it. INC-MPPT is implemented with the help of an integrator, which gain is $K$ and fed by the error signal. 


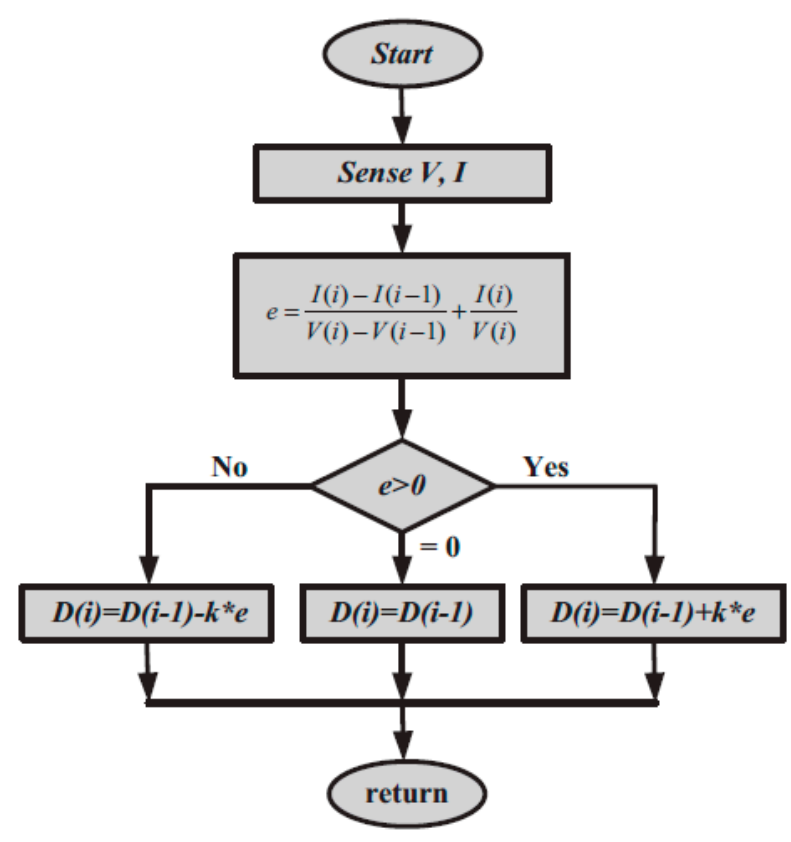

Figure 6. INC method flowchart.

\section{Moth-Flame Optimizer}

For many applications such as the optimal power flow problems, MFO has proved to be the most relevant, compared with many other optimization techniques [46]. The navigating mechanism of the moths, known as the transverse orientation principle, is simply described by the MFO. MFO that proposed by Mirjalili [39] has been used effectively in the field of tracking MPP by authors in Reference [47]. Moths are night-flying insects, sensing the moonlight, due to their unique navigation instinct. They maintain a constant angle in reference to the moon location, during flight, keeping a straight-line trajectory. This is named transverse orientation, but in the case of non-natural light sources, the moths do not go straight, but perform a spiral pass, although this source now is deemed a new attracting point for the moths.

The MFO technique is considered to be a population-based algorithm, so it can be simulated by the matrix below:

$$
M=\left(\begin{array}{cc}
m_{1,1} & m_{1, d} \\
m_{n, 1} & m_{n, d}
\end{array}\right)
$$

where $n$ is the number of moths and $d$ is the size of the search space in which the moths and flames positions vectors operate.

The corresponding moths' objective functions $O M$ are given by the following matrix:

$$
O M=\left(\begin{array}{c}
O M_{1} \\
O M_{2} \\
\vdots \\
O M_{n}
\end{array}\right)
$$

Similarly, the following flames matrix can be set as:

$$
F=\left(\begin{array}{ll}
F_{1,1} & F_{1, d} \\
F_{n, 1} & F_{n, d}
\end{array}\right)
$$

The $M F O$ procedure includes three-raw approximation functions indicated below:

$$
M F O=(I, P, T)
$$


where:

" $I$ " is the initial function that yields un-specified moth population, while their corresponding objective functions are:

$$
M(i, j)=(u l(i)-l l(i)) \cdot \operatorname{rand}(n, d)+l l(i)
$$

rand: random distribution function.

$$
O M=\text { FitnessFunction }(M)
$$

where: $u l$ and $l l$ denote the upper and lower thresholds of the variables, respectively.

According to the optimization procedure, this function should be first run to the end, followed by the population function " $P$ " until the termination criteria " $T$ " is met. Therefore, the function " $P$ " will guide the moths around the search location. The main moth position updating mechanism with respect to the flame is the logarithmic spiral function.

This position reference to the flame is updated as follows:

$$
M_{i}=S\left(M_{i}, F_{j}\right)
$$

The logarithmic spiral function can be represented by the following formula:

$$
S\left(M_{i}, F_{j}\right)=D_{i} \cdot e^{b t} \cdot \cos (2 \pi t)+F_{j}
$$

where: $M_{i}$ is the $i$ th moth order; $F_{j}$ is the order of the $j$ th flame; and $S$ denotes the spiral function, $D_{i}$ is the distance between the $i$ th moth and the $j$ th flame; $b$ is a constant; and $t$ is a random number in $[r, 1]$. Then, $r$ is the adaptive convergence constant that linearly decreases from -1 to -2 to fast-track convergence around the flames over the path of iterations.

$D$ is given by:

$$
D_{i}=\left|F_{j}-M_{i}\right|
$$

Exploration occurs at the moment when the consecutive position lies outside the enclosed space between the moth and the flame. It is said that the exploitation is converged, once the next position lies inside the space, shown by the arrow indicated by Equation (25) shows that the number of flames reasonably decreases over the iterations for assuring the balance between the exploration and exploitation. Therefore, the moth positions are updated only according to the best flame in the final iteration steps defined by:

$$
\text { flame no }=\text { round }\left(N_{f}-l \times \frac{N_{f}-1}{T_{\max }}\right)
$$

where:

" $l$ " is the current number of iteration, $N_{f}$ is the maximum number of flames, and $T_{\max }$ represents the maximum number of iterations.

The converter duty cycle is the most important key to control the DC-DC converter for maximizing the harvested energy from the HPVTEG system. Therefore, it has been selected to be the decision variable during the optimization process to maximize the output power of HPVTEG system. The relationship between the input voltage and load voltage of DC-DC converter can be formulated as follows;

$$
V_{\text {HPVTEG }}=(1-D) \times V_{\text {load }}
$$

where $V_{\text {HPVTEG }}$ is the HPVTEG voltage, and $V_{\text {load }}$ is the load voltage, $D$ is the duty cycle. The output power of HPVTEG system that represents the objective function can be estimated as follows;

$$
P_{P V T E G}=I_{H P V T E G} \times V_{H P V T E G}
$$


The procedure of MFO optimizer to extract the global maximum power of HPVTEG system under partial shading condition can be summarized as follows. Since MFO contains both moths and the flames populations that are moving in the search space. Equations (16) and (18) are used to show that moths and the flames are grouped in the matrixes $\mathrm{M}$ and $\mathrm{F}$ with same dimension. MFO optimizer starts the optimization process by n number of moths for every decision variable. For the case study, only one variable is considered. This variable is the duty cycle of DC-DC converter. The moths' positions initialization are based on Equation (20). For each value of moths (duty cycles), the HPVTEG system is operated and the corresponding system voltage and current are sensed. Then based on the measured current and voltage, the system power (OF) is estimated by Equation (27). Updating the moths' position with considering the flames positions will be carried out using Equation (23).

\section{Solar PV Panel Thermal Modeling}

In order to select the proper type of TEG, the temperature difference should be determined. Computational Fluid Dynamics (CFD) commercial package ANSYSFLUENT 15 is used to predict the temperature difference between the solar panel and the ambient. The solar panel geometry used in this study is based on the TALLMAX framed 72 cell module produce by Trina Solar Company. Only one solar panel is considered, with panel dimensions of $1.956 \times 0.922 \times 0.004 \mathrm{~m}^{3}$. The maximum solar radiation can be harvested by facing the PV panel toward the south with inclination angle of $20.5^{\circ}$ [3]. CFD predictions as a solution of a three-dimensional Navier-Stokes equations with Analysis of Systems (ANSYS) Fluent 15 is a very strong and effective tool. The computational model was specified to be three-dimensional, therefore a simple algorithm is used to couple fluid pressure and velocity. The residual converged solution of the continuous velocity component, turbulence kinetic energy is for energy below $10^{-6}$, and the turbulence dissipation rate is $10^{-3}$. The mesh is a uniform hexahedral element, meshing was specified along the boundary and swept later to cover the entire model volume. The computations in the present paper have mainly been carried out using $k-\varepsilon$ model, (under the two-equation model category). The temperature boundary condition, based on the average highest temperature during the year in Wadi Addwaser city as a case study, Riyadh Governorate, Kingdom of Saudi Arabia is (20.504 latitude, $45.2^{\circ}$ longitude) according to Reference [48] the average highest temperature is $30^{\circ} \mathrm{C}(303 \mathrm{~K})$. Therefore, the four sidewalls of the solar panel are set to constant temperature $30^{\circ} \mathrm{C}(303 \mathrm{~K})$, while the upper face is subjected to solar radiation of $800 \mathrm{~W} / \mathrm{m}^{2}$. To ensure that the results are independent of the mesh size, mesh dependence study is conducted by monitoring the temperature at three different positions across the center of the solar panel at $(x=0.85, y=0.461, z$ $=0.002),(x=1.5, y=0.461, z=0.002)$ and $(x=0.4, y=0.461, z=0.002)$. Three different number of mesh cells are adopted: 12568,21216 and 25376 . The temperature values at the three selected positions for different number of mesh cells are plotted in Figure 7; it is clear that there is a complete matching between the results of the last two meshes indicating that the solution is independent of mesh size for either of these two mesh, namely 21216 and 25376. The results obtained in this study are based on number of mesh cells of 21216. 


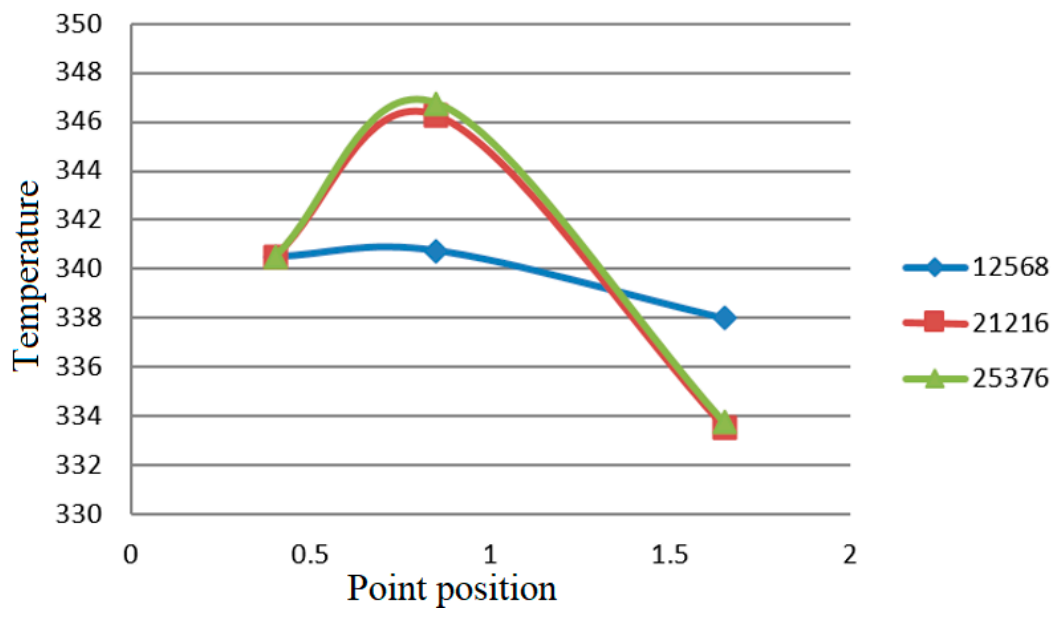

Figure 7. Mesh dependence study.

Figure 8 represents the temperature chart on the upper face of the solar panel. The highest temperature is $73{ }^{\circ} \mathrm{C}(346)$ occupying the central part of the panel, then the temperature decreased gradually towards the boundary temperature at the wall, because of the solar panel thermal conductivity.

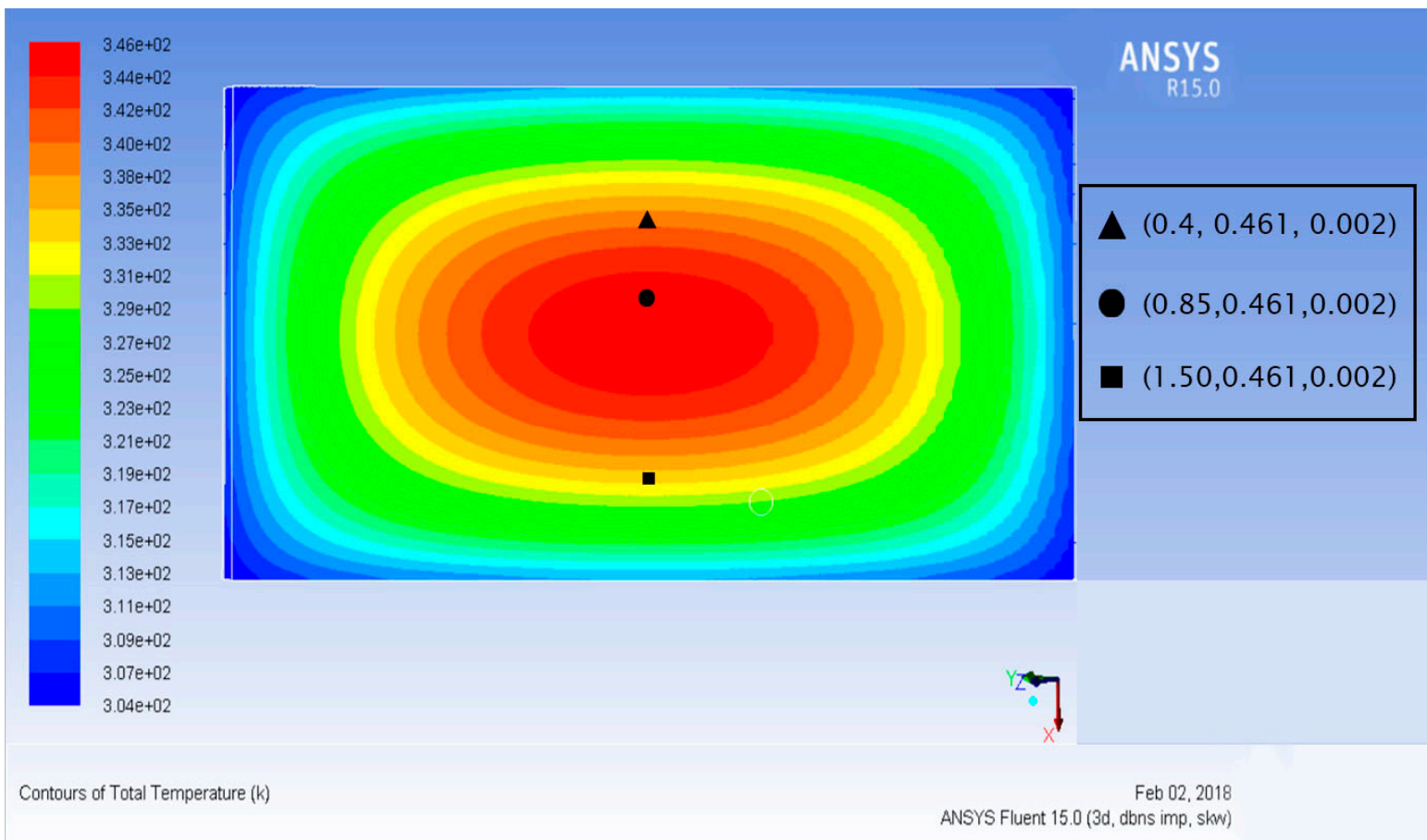

Figure 8. Temperature contours of the upper face of the solar panel.

\section{Results and Discussions}

As mentioned before, in this research a TEG bank consisting of 72 units, divided into two sub-groups is adopted. Each group includes six strings, having six serially connected units each. A MATLAB code is developed in order to simulate the bank and test it at different configurations. These two groups can be connected in series or in parallel based on system tracking mode of operation. Based on the temperature distribution of a solar panel shown in Figure 7, the hot side temperature of the TEG is assumed to be equal the highest temperature of $73^{\circ} \mathrm{C}$ occupying the central part of the solar panel. Whereas the cold side of TEG is equal to the atmosphere temperature of $30^{\circ} \mathrm{C}$. Therefore, the difference temperature between the two sides is $43^{\circ} \mathrm{C}$. For this difference in temperature, when the 
two groups of TEGs are connected in series, the voltage, current and power at MPP will be $13.80 \mathrm{~V}, 2.11$ A and $29.12 \mathrm{~W}$ respectively. Table 5 and Figure 9 show the power, current and voltage of TEG bank under different conditions.

Table 5. Voltage, current and power of a TEG bank under different configurations.

\begin{tabular}{llccc}
\hline \multicolumn{2}{c}{ TEG Configuration } & Voltage, V & Current, A & Power, W \\
\hline $\mathrm{Ns}=1$ & $\mathrm{~Np}=1$ & 1.15 & 0.35 & 0.40 \\
\hline $\mathrm{Ns}=6$ & $\mathrm{~Np}=12$ & 6.9 & 4.22 & 29.14 \\
\hline $\mathrm{Ns}=12$ & $\mathrm{~Np}=6$ & 13.80 & 2.11 & 29.13 \\
\hline
\end{tabular}
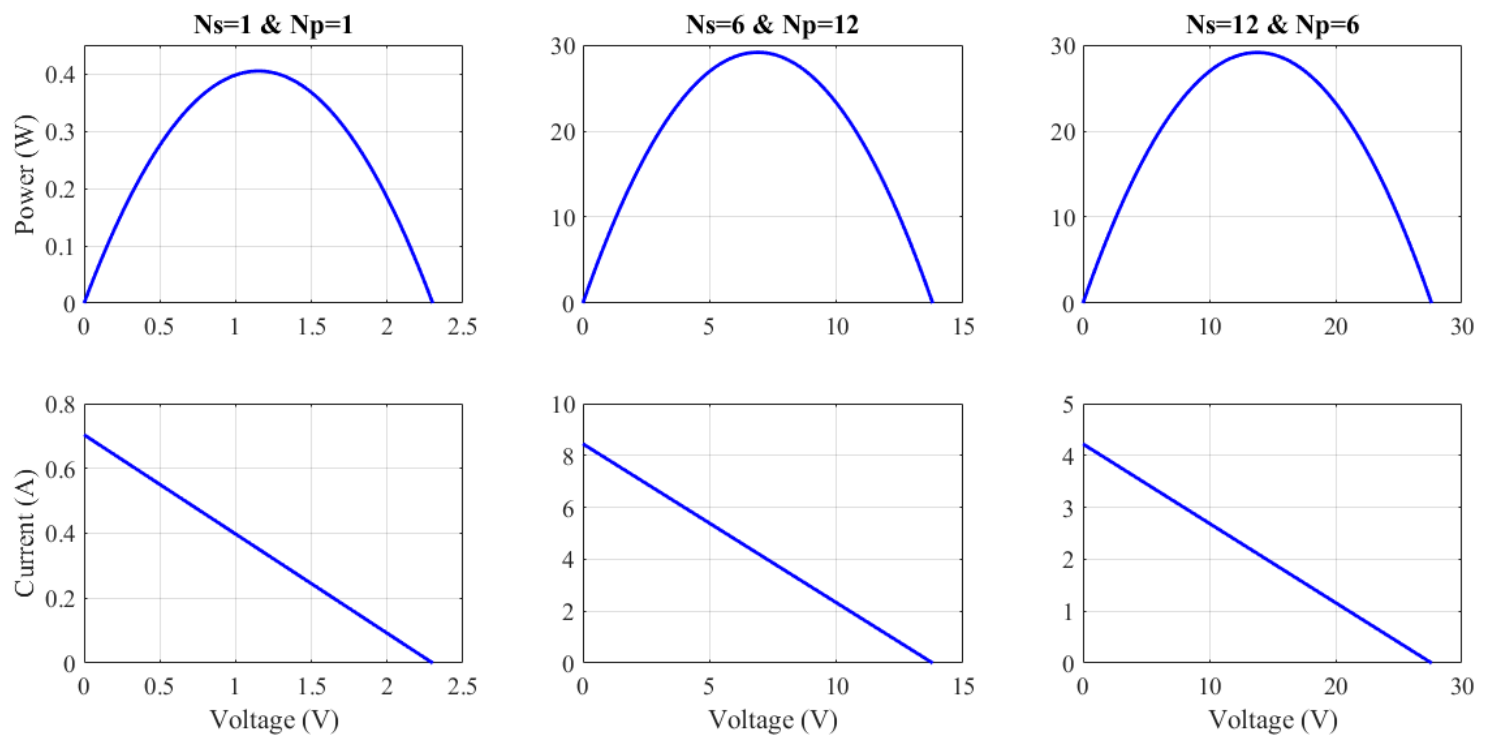

Figure 9. TEG voltage, current and power curves.

Four different cases are used to validate the proposed strategy. In the first case, the solar radiation distribution is uniform and equal to $800 \mathrm{~W} / \mathrm{m}^{2}$. In this case, and based on Table 6 and Figure 10, the PV panel current is 4.2 A. Therefore, the parallel connection of the two TEG sub-groups is better than the series connection. The situation is reversed in case of $400 \mathrm{~W} / \mathrm{m}^{2}$ uniform distribution, the series connection of the two TEG sub-groups is better than the parallel connection. In this case the power increased by 7.4\%. During partial shading condition, the PV panel current is reduced. Accordingly, the series connection of the two TEG groups is better than the series connection.

Table 6. Voltage, current and power at MPP under different configurations and conditions of PVTEG system.

\begin{tabular}{|c|c|c|c|c|c|c|}
\hline \multirow{2}{*}{$\begin{array}{c}\text { Configuration } \\
\# 1\end{array}$} & \multicolumn{2}{|c|}{ Solar Irradiance $\mathrm{W} / \mathrm{m}^{2}$} & $\begin{array}{c}\text { TEG } \\
\text { Configuration }\end{array}$ & \multirow{2}{*}{$\begin{array}{c}\text { Voltage, V } \\
45.45\end{array}$} & \multirow{2}{*}{$\begin{array}{c}\text { Current, A } \\
4.23\end{array}$} & \multirow{2}{*}{$\begin{array}{c}\text { Power, W } \\
192.44\end{array}$} \\
\hline & \multirow{3}{*}{ Uniform } & 800 & $\mathrm{Ns}=6 \quad \mathrm{~Np}=12$ & & & \\
\hline$\# 2$ & & 400 & $\mathrm{Ns}=12 \quad \mathrm{~Np}=6$ & 52.10 & 2.07 & 108.22 \\
\hline$\# 3$ & & 400 & $\mathrm{Ns}=6 \quad \mathrm{~Np}=12$ & 48.17 & 2.09 & 100.77 \\
\hline$\# 4$ & Non-uniform & $800,500,300$ & $\mathrm{Ns}=6 \quad \mathrm{~Np}=12$ & 36.21 & 2.71 & 98.11 \\
\hline
\end{tabular}



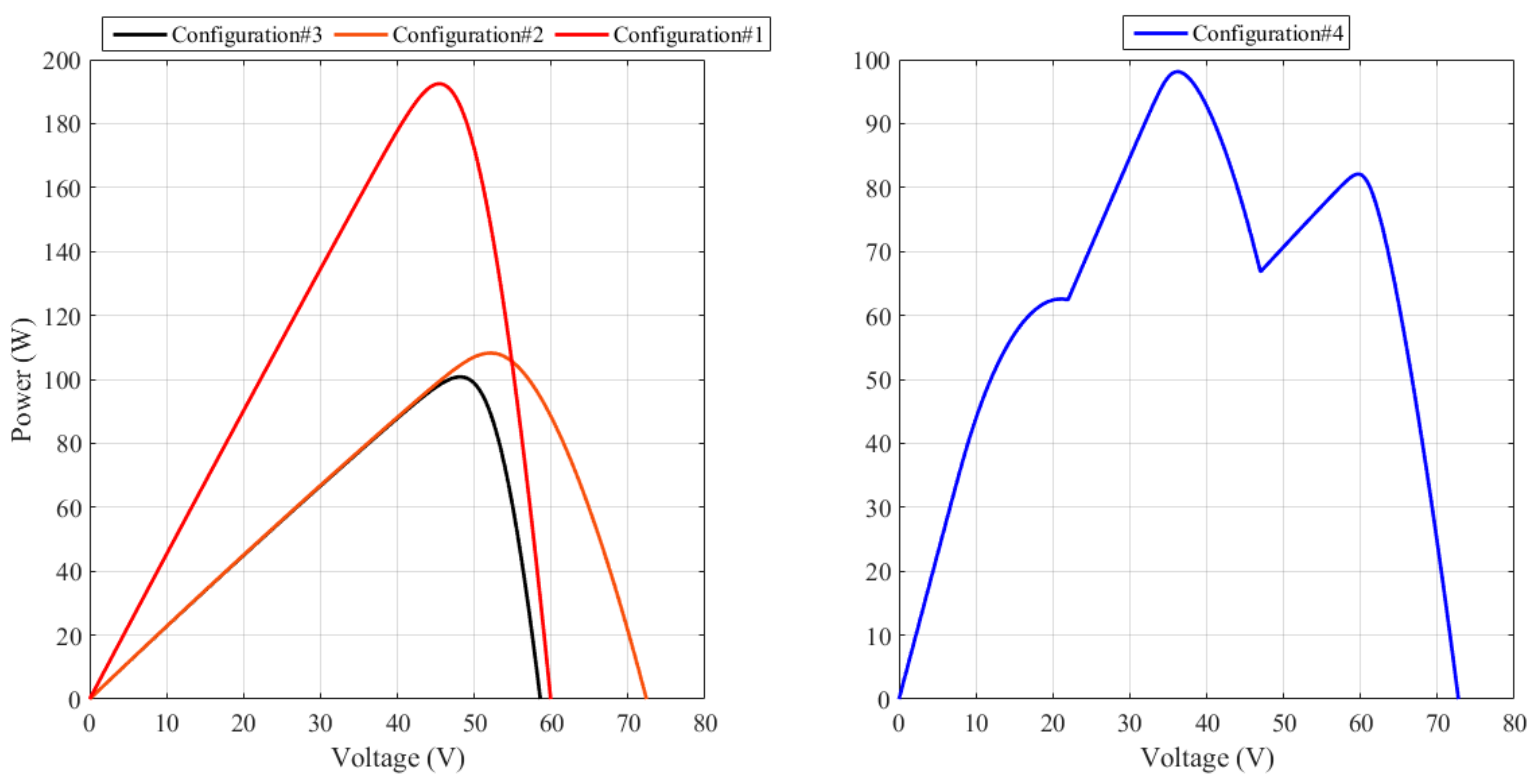

Figure 10. Power vs. voltage curves of HPVTEG under different conditions.

For the first case, the solar radiation is uniform so there is only single MPP of $192.44 \mathrm{~W}$ in the power against voltage curve. Based on the proposed strategy, the voltage across each bypass diode is approximately same. Therefore, the INC method is called and started the tracking process. Figure 11 illustrated the time variation of a HPVTEG system power, voltage, current and boost converter duty cycle, from which it is clear that the INC method is effectively, allocates the maximum power point with a tracking time of $0.1 \mathrm{~s}$.
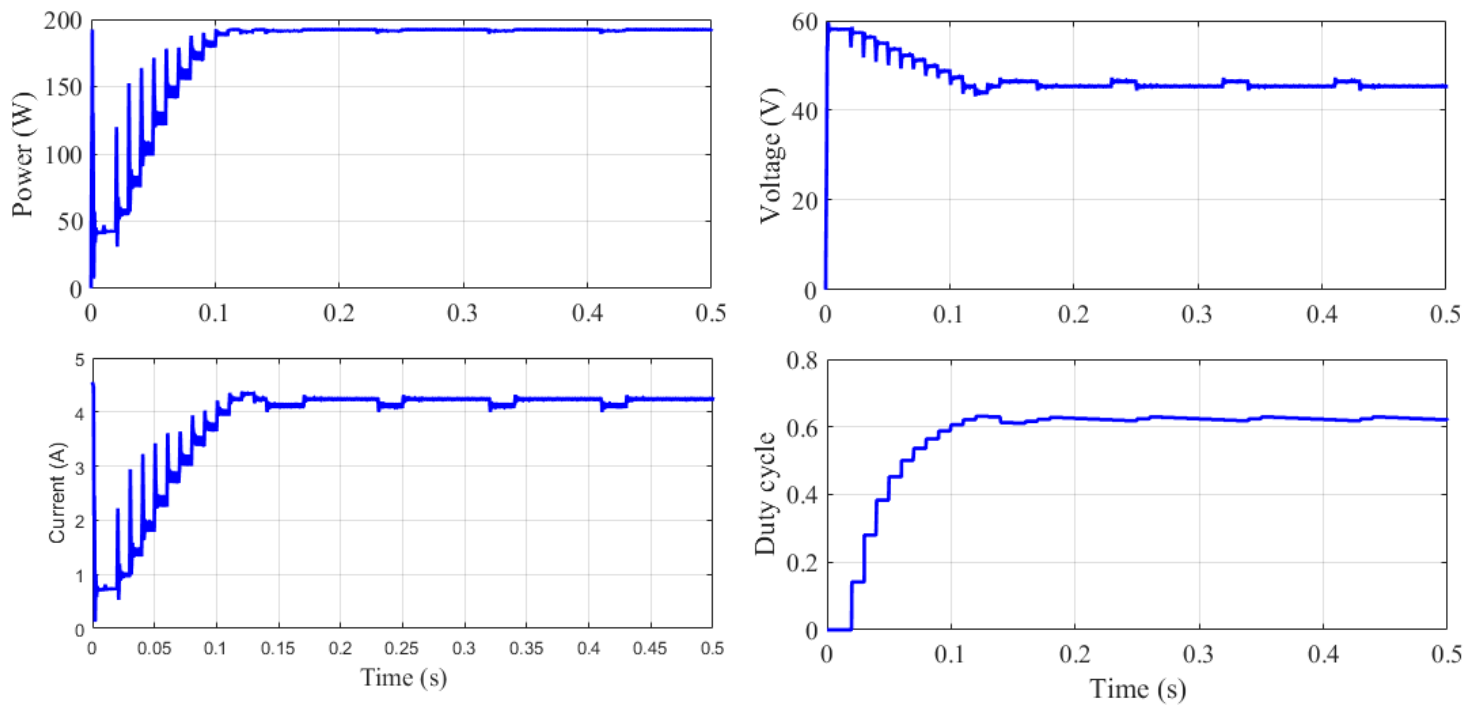

Figure 11. The performance of INC based MPPT under uniform irradiance.

For the fourth configuration, three different solar irradiances levels of $\left(800,500\right.$ and $\left.300 \mathrm{~W} / \mathrm{m}^{2}\right)$ are subjected to the PV panel. Under this situation, three MPPs located on the power/voltage curves since the number of maximum power point equal to the number of levels of solar irradiance. One global maximum power point of $98.11 \mathrm{~W}$ is allocated on the center power/voltage curve. Figure 12 shows the dynamic performance of INC method and MFO method under partial shading condition. From this figure, it can be noted that the MFO bypasses the first local peak power point $(83.5 \mathrm{~W})$ and fixed the optimal one of $98.11 \mathrm{~W}$. The conventional INC-based tracker caught the first local point of $83.5 \mathrm{~W}$, due to its disability to differentiate between the local and optimal maximum power point. At this 
situation the tracking efficiency increases by $17.5 \%$ using MFO in comparison with the INC method. The boost convertor duty cycle updating for each iteration in the case of MFO method is shown in Figure 13. Considering this figure, one can see that the optimizer starts the process by three values of duty cycles $(0.3,0.6$ and 0.8$)$. These values are updated for each iteration until the optimal duty cycle corresponding to global maximum power is determined. More case studies can be found in Appendix A (Table A1, Figures A1 and A2).
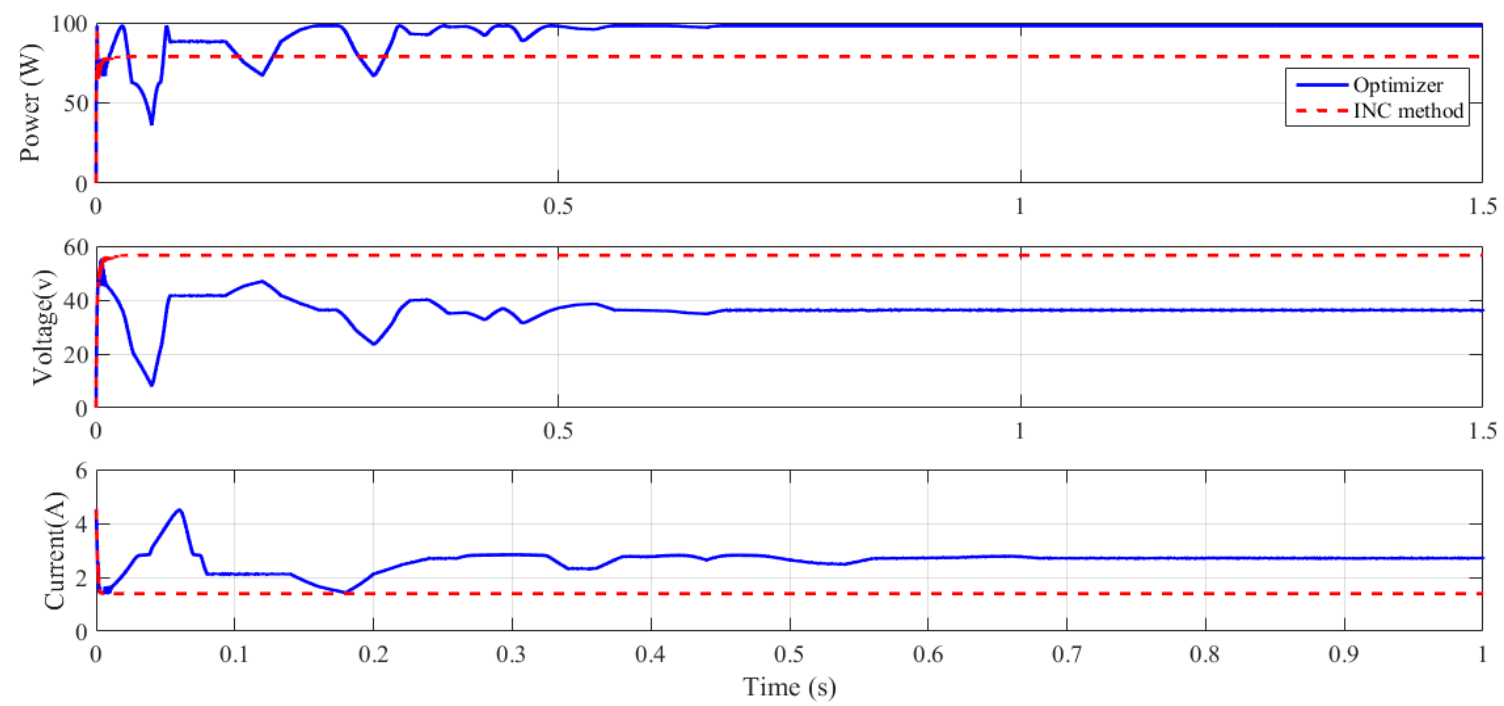

Figure 12. The performance of HPVTEG under PSC.

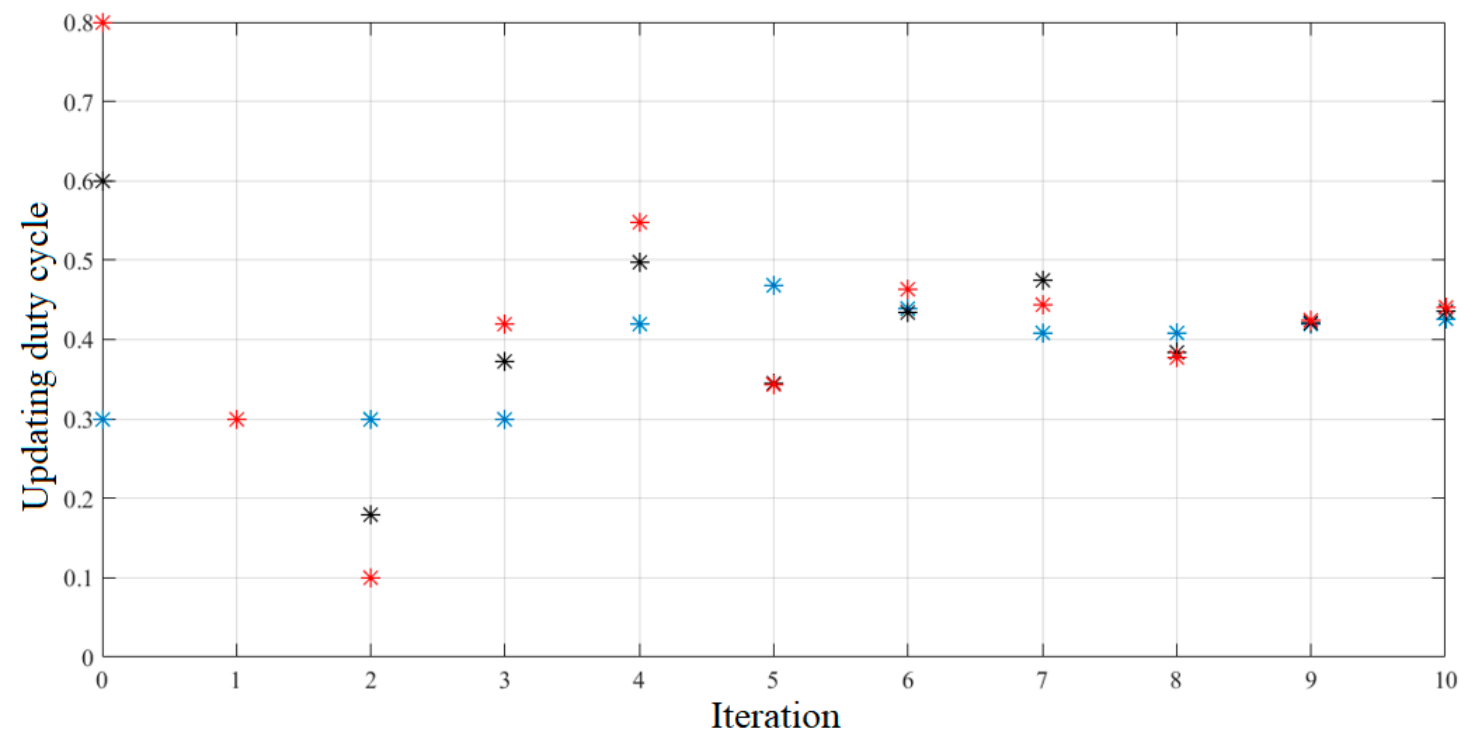

Figure 13. Updating of boost converter duty cycle for each iteration.

\section{Conclusion}

Improving energy conversion efficiency of PV system through thermoelectric generator (TEG) integration is presented in this paper. This is achieved by capturing the waste heat and using it as an auxiliary energy production source. The temperature difference between cold and hot side of the TEG is predicted by using CFD commercial package ANSYS FLUENT 15. The modeling and performance evaluation of system are carried out using the MATLAB software (version 2018, mathworks: MA, US). The system maximum power is harvested through a proposed a hybrid MPPT algorithm (INC-MFO) combining incremental conductance (INC) and moth-flame optimizer (MFO) to achieve better adaptability in various environment. The incorporation of two different algorithms 
combines the advantages of both, thereby providing faster tracking speed with uniform radiation distribution and high accuracy with non-uniform radiation distribution. The proposed strategy calls the INC method to track MPP under normal condition and calls MFO optimizer to catch the optimal MPP under non-uniform distribution. The obtained results reveal that the proposed strategy performed best in both dynamic response and steady-state in cases of uniform and non-uniform irradiance distribution.

Author Contributions: conceptualization, H.R. and M.R.G.; methodology, H.R. and M.R.G.; software, H.R., O.Y. and M.H.; validation, H.R., Z.M.A., O.A., O.Y., M.R.G. and M.H.; formal analysis, H.R., Z.M.A., O.A., O.Y. and M.R.G.; investigation, H.R., Z.M.A., O.A., O.Y., M.R.G. and M.H.; writing-original draft preparation, H.R., Z.M.A., O.A., O.Y., M.R.G. and M.H.; writing—review and editing, H.R., Z.M.A., O.A., O.Y., M.R.G. and M.H.

Funding: This research received no external funding.

Conflicts of Interest: The authors declare no conflicts of interest.

\section{Appendix A}

Additional case studies

Table A1. Voltage, current and power at MPP under different scenarios.

\begin{tabular}{|c|c|c|c|c|c|c|c|}
\hline Scenario & \multicolumn{2}{|c|}{ Solar Irradiance $W / \mathrm{m}^{2}$} & \multicolumn{2}{|c|}{$\begin{array}{c}\text { TEG } \\
\text { Configuration }\end{array}$} & \multirow{2}{*}{$\begin{array}{c}\text { Voltage, V } \\
54.9\end{array}$} & \multirow{2}{*}{$\begin{array}{c}\text { Current, A } \\
1.55\end{array}$} & \multirow{2}{*}{$\begin{array}{c}\text { Power, W } \\
85.0\end{array}$} \\
\hline \#A1 & \multirow{2}{*}{ Uniform } & 300 & $\mathrm{Ns}=12$ & $\mathrm{~Np}=6$ & & & \\
\hline \#A2 & & 500 & $\mathrm{Ns}=12$ & $\mathrm{~Np}=6$ & 49.32 & 2.59 & 127.8 \\
\hline \#A3 & \multirow{2}{*}{ Non-uniform } & $800,600,300$ & $\mathrm{Ns}=12$ & $N p=6$ & 33.24 & 3.18 & 105.7 \\
\hline \#A4 & & $900,500,200$ & $\mathrm{Ns}=12$ & $\mathrm{~Np}=6$ & 33.64 & 2.7 & 98.6 \\
\hline
\end{tabular}
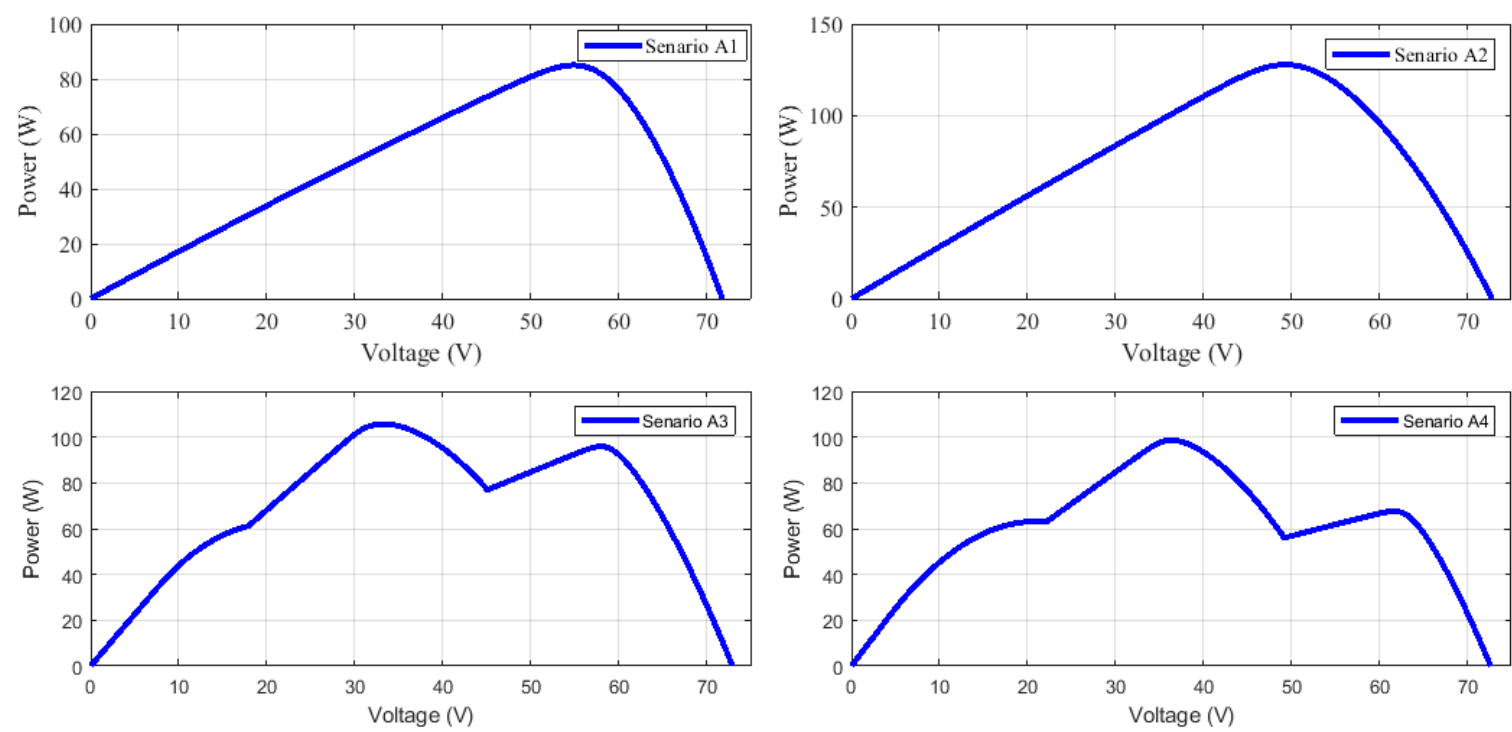

Figure A1. Power against voltage curves under different scenarios. 

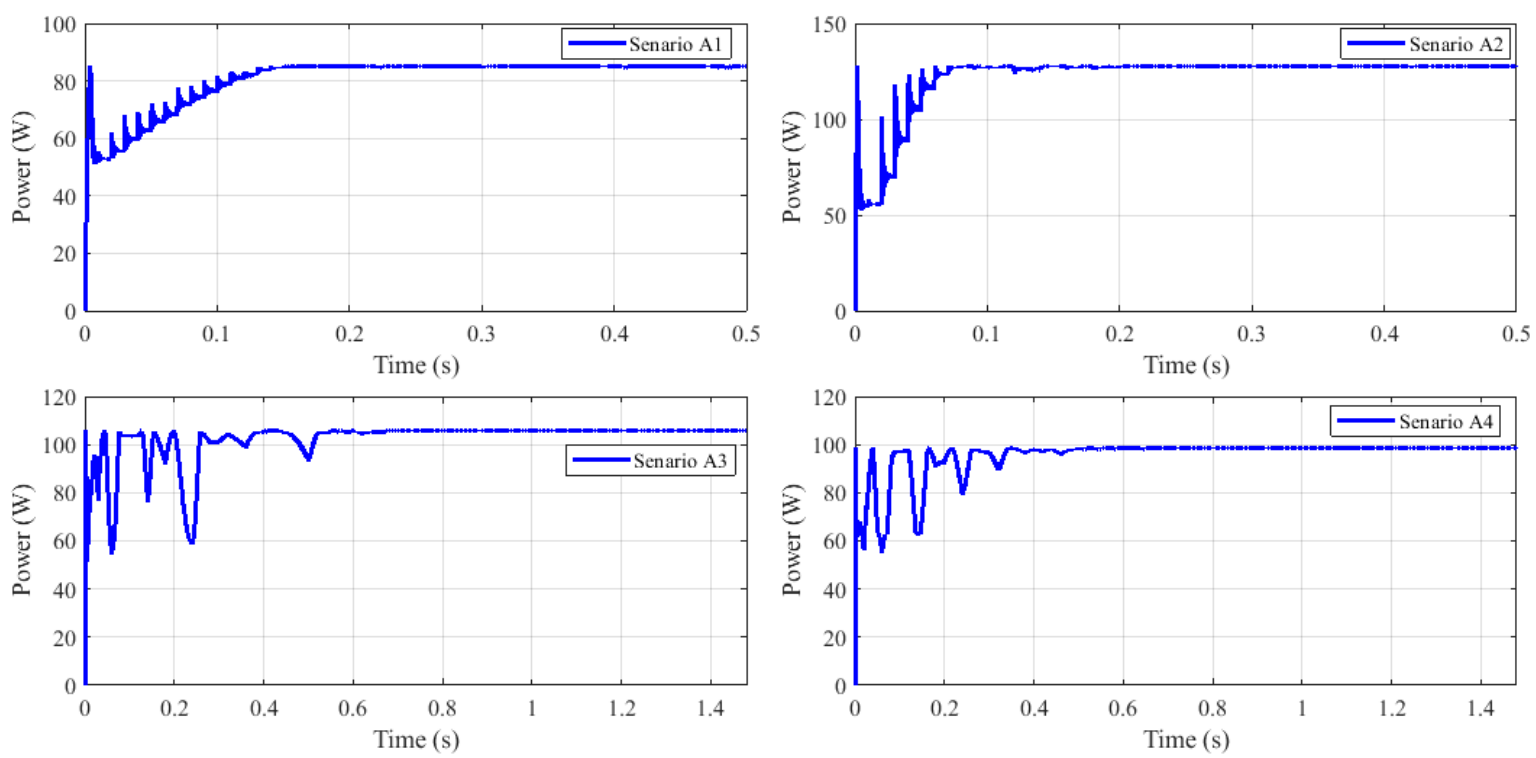

Figure A2. The performance of HPVTEG under different scenarios.

\section{References}

1. Marmoush, M.M.; Rezk, H.; Shehata, N.; Henry, J.; Gomaa, M.R. A novel merging Tubular Daylight Device with Solar Water Heater-Experimental study. Renew. Energy 2018, 125, 947-961. [CrossRef]

2. Hemeida, M.G.; Rezk, H.; Hamada, M.M. A comprehensive comparison of STATCOM versus SVC-based fuzzy controller for stability improvement of wind farm connected to multi-machine power system. Electr. Eng. 2018, 100, 935-951. [CrossRef]

3. Rezk, H.; Tyukhov, I.; Raupov, A. Experimental implementation of meteorological data and photovoltaic solar radiation monitoring system. Int. Trans. Electr. Energy Syst. 2015. [CrossRef]

4. Rezk, H.; Tyukhov, I.; Al-Dhaifallaha, M.; Tikhonov, A. Performance of data acquisition system for monitoring PV system parameters. Measurement 2017, 104, 204-211. [CrossRef]

5. Rezk, H.; El-Sayed, A.H.M. Sizing of a Stand Alone Concentrated Photovoltaic System in Egyptian Site. Int. J. Electr. Power Energy Syst. 2015, 45, 325-330. [CrossRef]

6. Rezk, H. A comprehensive sizing methodology for stand-alone battery-less photovoltaic water pumping system under the Egyptian climate. Cogent Eng. 2016, 3, 1242110. [CrossRef]

7. Rezk, H.; Dousoky, G.M. Technical and economic analysis of different configurations of stand-alone hybrid renewable power systems-A case study. Renew. Sustain. Energy Rev. 2016, 62, 941-953. [CrossRef]

8. Montecucco, A.; Knox, A.R. Maximum Power Point Tracking Converter Based on the Open-Circuit Voltage Method for Thermoelectric Generators. IEEE Trans. Power Electron. 2015, 30, 828-839. [CrossRef]

9. Kim, R.; Lai, J.; York, B.; Koran, A. Analysis and Design of Maximum Power Point Tracking Scheme for Thermoelectric Battery Energy Storage System. IEEE Trans. Ind. Electron. 2009, 56, 3709-3716.

10. Bjørk, R.; Nielsen, K.K. The performance of a combined solar photovoltaic (PV) and thermoelectric generator (TEG) system. Sol. Energy 2015, 120, 187-194. [CrossRef]

11. Zhang, J.; Xuan, Y.; Yang, L. A novel choice for the photovoltaic-thermoelectric hybrid system: The perovskite solar cell. Int. J. Energy Res. 2016, 40, 1400-1409. [CrossRef]

12. Zhang, X.; Chau, K.T. An automotive thermoelectric-photovoltaic hybrid energy system using maximum power point tracking. Energy Convers. Manag. 2011, 52, 641-647. [CrossRef]

13. Daniel, T.C.; Petru, A.C.; Daniela, C. Characterization of Photovoltaic-Thermoelectric-Solar Coll ector Hybrid Systems in Natural Sunlight Conditions. J. Energy Eng. 2017. [CrossRef]

14. Zhang, X.; Chau, K.T.; Chan, C.C. Design and Implementation of a Thermoelectric-Photovoltaic Hybrid Energy Source for Hybrid Electric Vehicles. In Proceedings of the EVS24, Stavanger, Norway, 13-16 May 2009.

15. Edgar, A.; Chávez, U.; Yuri, V.V. Design and Investigation of Solar Hybrid Electric/Thermal System with Sun-tracking Concentrator, Photovoltaic and Thermoelectric Generators. In Proceedings of the 7th WSEAS International Conference on Energy and Environment, Kos Island, Greece, 14-17 July 2012; pp. 336-341. 
16. Deng, Y.; Zhu, W.; Wang, Y.; Shi, Y. Enhanced performance of solar-driven photovoltaic-thermoelectric hybrid system in an integrated design. Sol. Energy 2013, 88, 182-191. [CrossRef]

17. van Sark, W.G.J.H.M. Feasibility of photovoltaic-Thermoelectric hybrid modules. Appl. Energy 2011, 88, 2785-2790. [CrossRef]

18. Park, K.-T.; Shin, S.-M.; Tazebay, A.S.; Um, H.-D.; Jung, J.-Y.; Jee, S.-W.; Oh, M.W.; Park, S.D.; Yoo, B.; Yu, C.; et al. Lossless hybridization between photovoltaic and thermoelectric devices. Sci. Rep. 2013, 3, 2123. [CrossRef] [PubMed]

19. Beeri, O.; Rotem, O.; Hazan, E.; Katz, E.A.; Braun, A.; Gelbstein, Y. Hybrid photovoltaic-thermoelectric system for concentrated solar energy conversion: Experimental realization and modeling. J. Appl. Phys. 2015, 118, 115104. [CrossRef]

20. Cotfas, D.T.; Cotfas, P.A.; Machidon, O.M.; Ciobanu, D. Investigation of the photovoltaic cell/thermoelectric element hybrid system performance. IOP Conf. Ser. Mater. Sci. Eng. 2016, 133, 12037. [CrossRef]

21. Zhu, W.; Deng, Y.; Wang, Y.; Shen, S.; Gulfam, R. High-performance photovoltaic-thermoelectric hybrid power generation system with optimized thermal management. Energy 2016, 100, 91-101. [CrossRef]

22. Kossyvakis, D.N.; Voutsinas, G.D.; Hristoforou, E.V. Experimental analysis and performance evaluation of a tandem photovoltaic-thermoelectric hybrid system. Energy Convers. Manag. 2016, 117, 490-500. [CrossRef]

23. Hsueh, T.-J.; Shieh, J.-M.; Yeh, Y.-M. Hybrid Cd-free CIGS solar cell/TEG device with ZnO nanowires. Prog. Photovolt. Res. Appl. 2015, 23, 507-512. [CrossRef]

24. Wang, N.; Han, L.; He, H.; Park, N.-H.; Koumoto, K. A novel high-performance photovoltaic-thermoelectric hybrid device. Energy Environ. Sci. 2011, 4, 3676-3679. [CrossRef]

25. Chen, T.; Guai, G.H.; Gong, C.; Hu, W.; Zhu, J.; Yang, H. Thermoelectric Bi2Te3-improved charge collection for high-performance dye-sensitized solar cells. Energy Environ. Sci. 2012, 5, 6294-6298. [CrossRef]

26. Zhou, Z.; Yang, J.; Jiang, Q.; Li, W.; Luo, Y.; Hou, Y. Large improvement of device performance by a synergistic effect of photovoltaics and thermoelectrics. Nano Energy 2016, 22, 120-128. [CrossRef]

27. Zhang, Y.; Fang, J.; He, C.; Yan, H.; Wei, Z.; Li, Y. Integrated energy-harvesting system by combining the advantages of polymer solar cells and thermoelectric devices. J. Phys. Chem. 2013, 117, 24685-24691. [CrossRef]

28. Zhang, J.; Xuan, Y.; Yang, L. Performance estimation of photovoltaic-thermoelectric hybrid systems. Energy 2014, 78, 895-903. [CrossRef]

29. Zeb, K. A survey on waste heat recovery: Electric power generation and potential prospects within Pakistan. Renew. Sustain. Energy Rev. 2017, 75, 1142-1155. [CrossRef]

30. Guo, X.; Zhang, Y.; Qin, D.; Luo, Y.; Li, D.; Pang, Y. Hybrid tandem solar cell for concurrently converting light and heat energy with utilization of full solar spectrum. J. Power Sources 2010, 195, 7684-7690. [CrossRef]

31. Li, G.; Zhao, X.; Ji, J. Conceptual development of a novel photovoltaic-thermoelectric system and preliminary economic analysis. Energy Convers. Manag. 2016, 126, 935-943. [CrossRef]

32. Rezk, H.; Eltamaly, A.M. A comprehensive comparison of different MPPT techniques for photovoltaic systems. Sol. Energy 2015, 112, 1-11. [CrossRef]

33. Rezk, H.; Hasaneen, E.-S. A new MATLAB/Simulink model of triple-junction solar cell and MPPT based on artificial neural networks for photovoltaic energy systems. Ain Shams Eng. J. 2015, 6, 873-881. [CrossRef]

34. Rezk, H.; Fathy, A.; Abdelaziz, A.Y. A comparison of different global MPPT techniques based on meta-heuristic algorithms for photovoltaic system subjected to partial shading conditions. Renew. Sustain. Energy Rev. 2017, 74, 377-386. [CrossRef]

35. Fathy, A.; Rezk, H. A novel methodology for simulating maximum power point trackers using mine blast optimization and teaching learning based optimization algorithms for partially shaded photovoltaic system. J. Renew. Sustain. Energy 2016, 8, 023503. [CrossRef]

36. Rezk, H.; Fathy, A. Simulation of global MPPT based on teaching-learning-based optimization technique for partially shaded PV system. Electr. Eng. 2016. [CrossRef]

37. Diab, A.A.Z.; Rezk, H. Global MPPT based on flower pollination and differential evolution algorithms to mitigate partial shading in building integrated PV system. Sol. Energy 2017, 157, 171-186. [CrossRef]

38. Wolpert, D.H.; Macready, W.G. No free lunch theorems for optimization. IEEE Trans. Evol. Comput. 1997, 1, 67-82. [CrossRef]

39. Mirjalili, S. Knowledge-Based Systems Moth-flame optimization algorithm: A novel nature-inspired heuristic paradigm. Knowl.-Based Syst. 2015, 89, 228-249. [CrossRef] 
40. Datasheet “TSM-205DA01A.05”. Available online: https://www.solarreviews.com/buyers-guide/solarpanels/trina-solar/trina27872tsm205da01a05 (accessed on 29 June 2019).

41. Lineykin, S.; Ben-Yaakov, S. Modeling and Analysis of Thermoelectric Modules. IEEE Trans. Ind. Appl. 2007, 43, 505-512. [CrossRef]

42. Shanmugam, S.; Eswaramoorthy, M.; Veerappan, A.R. Modeling and Analysis of a Solar Parabolic Dish Thermoelectric Generator. Energy Sources Part A 2014, 36, 1531-1539. [CrossRef]

43. Datasheet "TE-MOD-1W2V-40S". Available online: http://www.tegpro.com/datasheets/TE-MOD-1W2V-40S. pdf (accessed on 29 June 2019).

44. Ahmed, E.M.; Shoyama, M. Scaling factor design issues in variable step size incremental resistance MPPT in PV systems. In Proceedings of the 2011 IEEE Ninth International Conference on Power Electronics and Drive Systems, Singapore, 5-8 December 2011. [CrossRef]

45. Al-Dhaifallah, M.; Nassef, A.M.; Hegazy, R.; Nisar, K.S. Optimal parameter design of fractional order control based INC-MPPT for PV system. Sol. Energy 2018, 159, 650-664. [CrossRef]

46. Bachir, B.; Lakhdar, C.; Saliha, C. Optimal Power Flow using the Moth Flam Optimizer: A Case Study of the Algerian Power System. Indones. J. Electr. Eng. Comput. Sci. 2016, 13, 431-445.

47. Mohamed, A.M.; Diab, A.A.Z.; Rezk, H. Partial shading mitigation of PV systems via different meta-heuristic techniques. Renew. Energy 2019, 130, 1159-1175. [CrossRef]

48. Available online: https://weatherspark.com/y/148812/Average-Weather-at-Wadi-al-Dawasir-DomesticAirport-Saudi-Arabia-Year-Round (accessed on 18 April 2019).

(C) 2019 by the authors. Licensee MDPI, Basel, Switzerland. This article is an open access article distributed under the terms and conditions of the Creative Commons Attribution (CC BY) license (http://creativecommons.org/licenses/by/4.0/). 